\title{
IMPROVING QUALITY CONTROL OF SILUMINIAL CASTINGS USED IN THE AUTOMOTIVE INDUSTRY
}

\author{
${ }^{1}$ Karolina CZERWIŃSKA, ${ }^{2}$ Renata DWORNICKA, ${ }^{3}$ Andrzej PACANA \\ ${ }^{1}$ Rzeszow University of Technology, Rzeszow, Poland, EU, ORCID ID: 0000-0003-2150-0963, \\ k.czerwinska@prz.edu.pl, \\ ${ }^{2}$ Cracow University of Technology, Cracow, Polska, EU, ORCID ID: 0000-0002-2979-1614, \\ renata.dwornicka@mech.pk.edu.pl, \\ ${ }^{3}$ Rzeszow University of Technology, Rzeszow, Poland, EU, ORCID ID: 0000-0003-1121-6352, \\ app@prz.edu.pl,
}

https://doi.org/10.37904/metal.2020.3661

\begin{abstract}
The aim of the study is to identify the causes of non-compliance of castings and ultimately, using quality management tools (5W2H I diagram Ishikawa), to reduce or eliminate the number of such non-compliance. The research was carried out using visual, luminescence and metallographic tests and the product was a diesel engine piston casting. The study identified clusters of rows in the area of sealing canals and specified their cause - inadequate quality of the charge. So far, no analyses of quality problems using a sequential quality management methodology have been carried out in the company, so that the implemented corrective actions did not lead to the full achievement of quality objectives. The sequential method presented in the paper, combining diagnostic and control tests and quality management tools, is a universal way to monitor the quality level of products and to quickly correct any nonconformities. The presented method can be used in enterprises producing products from ferromagnetic, non-ferromagnetic and non-metallic materials (due to the effectiveness of the luminescence method).
\end{abstract}

Keywords: Quality control, piston silumines, luminescent testing, quality management tools

\section{INTRODUCTION}

Continuous technological development contributes to a dynamic increase in the loads on the equipment and machines used, which leads to an increase in the requirements for structural materials. This development influences the creation of new technologies for manufacturing metals and alloys with better strength properties [1-3]. At present, reciprocating internal combustion engines are the most important source of energy used to drive motor vehicles. Of all the parts that make up an internal combustion engine, the piston is the one most exposed to thermal damage. This element is a movable part of the combustion chamber and must therefore be resistant to high temperatures and pressures [4]. The legal conditions relating to the reduction of toxic emissions of exhaust gases generated by reciprocating internal combustion engines force vehicle manufacturers to improve existing casting alloys and products - in terms of both specific physicochemical properties and performance characteristics - is one of the most important directions for the development of the global foundry industry [5-7].

Comprehensive methods are constantly being sought to detect incompatibilities, but also to prevent them by detecting the sources of their origin or even looking for causes that cause problems within these sources. The methods enabling the implementation of the indicated activities are quality management methods, which, when skillfully applied, allow to increase the quality level of the offered products $[8,9]$. 


\section{PISTON SILUMINS}

Equal research is currently being carried out on the quality of reciprocating silumin products, including, for example, the improvement of the structure and properties of the material [10-13], impact of manufacturing technology on the properties of castings [14-17], evaluation of the dimensional stability of the product [18] or the tribological behavior of the piston alloy [19]. Despite attempts to improve the structure of properties of silumin castings, attention should also be paid to quality control of these castings $[6,20]$. A model solution to the issue of evaluating the condition of piston silumin castings is to use non-destructive testing, the application of which does not affect the condition of the controlled product. This applies to production quality control during product manufacturing and in-service testing on diesel engines. The importance of NDT in automotive technology is particularly important also due to the relatively low values of safety factors determined when designing automotive structures [21,22]. The analysis of publications related to the inspection of piston castings indicates that attempts are made to use single non-destructive testing (e. g. The following parameters are available: X-ray [11], ultrasound [20,23,24], infrared thermography [14], eddy currents [25]), depending on the purpose, construction and dimensions of the pistons. Therefore, it is advisable to develop a sequential method to control piston castings.

\section{ANALYSIS}

\subsection{Aim, scope and subject matter}

The aim of the study is to diagnose, by means of visual, luminescence and metallographic testing methods, the condition of an aluminum piston casting The aim of the study is also to determine the sources of noncompliance of castings and ultimately, by means of quality management tools (Ishikawa diagram and 5W2H), to reduce the occurrence of non-compliant products or to eliminate them completely.

Due to an increase in complaints and the number of identified non-compliant products during the interoperational inspection (19\% compared to the previous quarter), the subject of the tests was a casting of the piston intended for the internal combustion engine of a passenger vehicle of Toyota (Figure 1).

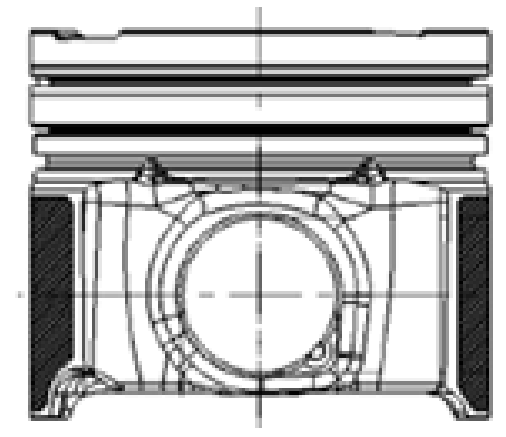

Figure 1 Subject of the tests - Diesel engine piston projection

The survey concerned a batch of products made in Q2 2019 in one of the automotive companies located in the southern part of Poland. The company produces aluminum and steel pistons. The scope of visual and luminescence tests covered the surfaces of the entire casting, while metallographic analysis of areas where discontinuities of the material were detected. In order to assess the possibility of detecting surface and nearsurface discontinuities in the whole volume of the material tested, experimental tests were carried out.

\subsection{Alloy characteristics B2}

Alloy B2 is an eutectic silicone-aluminum alloy for diesel and gasoline engine pistons in light vehicles. The chemical composition of alloy B2 is shown in Table 1. Stop B2 has no national or international equivalents. 
Table 1 Chemical composition of the alloy B2

\begin{tabular}{|c|c|c|c|c|c|c|c|c|c|c|c|c|c|}
\hline Episode & $\mathbf{S i}$ & $\mathbf{C u}$ & $\mathbf{M g}$ & $\mathbf{N i}$ & $\mathbf{F e}$ & $\mathbf{M g}$ & $\mathbf{Z n}$ & $\mathbf{P b}$ & $\mathbf{S n}$ & $\mathbf{T i}$ & $\mathbf{Z r}$ & $\mathbf{V}$ & $\mathbf{A l}$ \\
\hline Min, (\%) & 12.0 & 3.7 & 0.5 & 1.7 & - & - & - & - & - & - & - & - & $\begin{array}{c}\text { rest of the } \\
\text { warehouse }\end{array}$ \\
\hline Max, (\%) & 14.5 & 5.2 & 1.5 & 3.2 & 0,7 & 0.2 & 0.1 & 0.08 & 0.2 & 0.2 & 0.2 & 0.2 & \\
\hline
\end{tabular}

\subsection{Course of research}

The methods used for quality control of piston castings - identification and characterization of nonconformities - were visual inspection and penetration testing, as well as quality management techniques (Ishikawa diagram, $5 \mathrm{~W} 2 \mathrm{H}$ method). Correlation of selected diagnostic methods and their order of application is shown in Figure 2.

\begin{tabular}{|c|}
\hline Visual tests \\
\hline Luminescence test \\
\hline Metallographic exam ination
\end{tabular}

Figure 2 Sequence of methods used to analyse nonconformities and identify the source of their occurrence

Visual examination in a company is performed by employees after each technological operation. Penetration tests were performed in a specially adapted room and consisted of applying the penetrant to the piston surface (time of interaction 10-30 $\mathrm{min}$ ), and then cleaning the surface and applying the developer. In the examination, the samples for metallographic testing were cut out of the defective areas of the piston casting on a metallographic cutter and then encapsulated in resin. The next step was to grind and polish the samples on the Saphir 530. The metallographic specimens were etched with $5 \%$ aqueous solution of HF acid. The microstructure was observed on the Zeiss Neophot 2 metallographic microscope. The non-conformity has been analyzed and characterized by the $5 \mathrm{~W} 2 \mathrm{H}$ method, the Ishikawa diagram and the ABCD-Suzuki method. The $5 \mathrm{~W} 2 \mathrm{H}$ method was used to characterize in a short and clear way the most important information about the problem. The Ishikawa diagram was used to identify potential causes of non-compliance, while using the $A B C D$ - Suzuki method, a team of experts determined the importance and rank of the individual causes.

\section{RESULTS OF ANALYSIS}

The research was carried out by a working team consisting of: the Head of the Department of Health and Consumer Protection, the quality manager, chief technologist, foundry manager and specialist in the field of quality assurance research. The study analyzed all non-compliant products identified in Q2 2019. and products advertised by customers. An example of obtained results of visual, luminescence and microscopic observations of the area of sealing channels of a piston casting is shown in Figure 3. The results presented relate to the most serious and most frequent non-compliance. The obtained results indicate the occurrence in the medium-loaded zone of incompatibilities of unacceptable size - clusters of rows. Localized discontinuity disqualifies the piston. In the next step, the working group, set up to solve the problem, made a Gemba of fights and then carried out a $5 \mathrm{~W} 2 \mathrm{H}$ analysis in order to precisely characterize the problem. The $5 \mathrm{~W} 2 \mathrm{H}$ analysis 
showed that during a visual inspection an employee noticed a discrepancy in the area of sealing channels. After the luminescence test and microstructure observation, clusters of crowds were identified which disqualified the piston. The problem concerned 30\% of manufactured products in Q2 2019. In the next step, a diagram of Ishikawa was made in order to identify the most probable causes of non-compliance and classify them according to the following categories: man, machine, material, method, management (Figure 4). Based on the Ishikawa diagram of material noncompliance, i. e. the plunger castings located in the area of the sealing channels, a significant number of potential causes of non-compliance have been identified.

a)

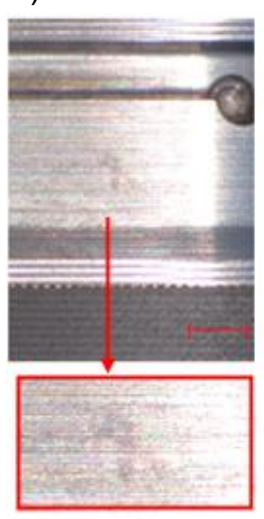

b)

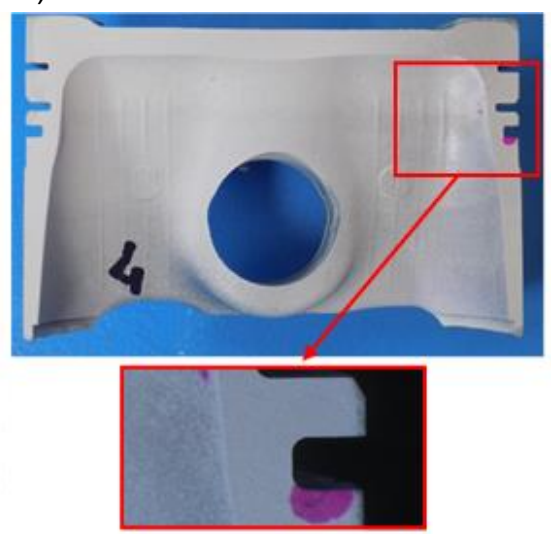

c)

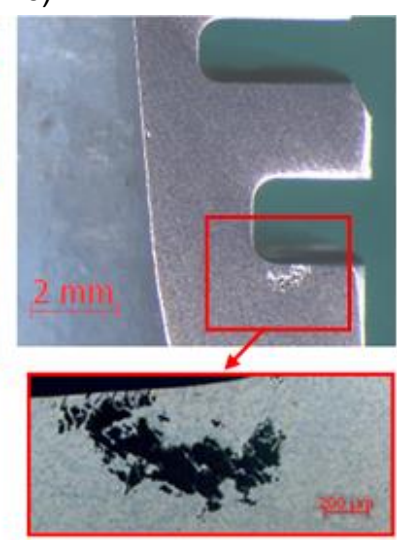

Figure 3 Result of the visual examination (a); view of the non-compliance on the cross-section after color luminescence (b); c) microstructure in the non-compliance zone

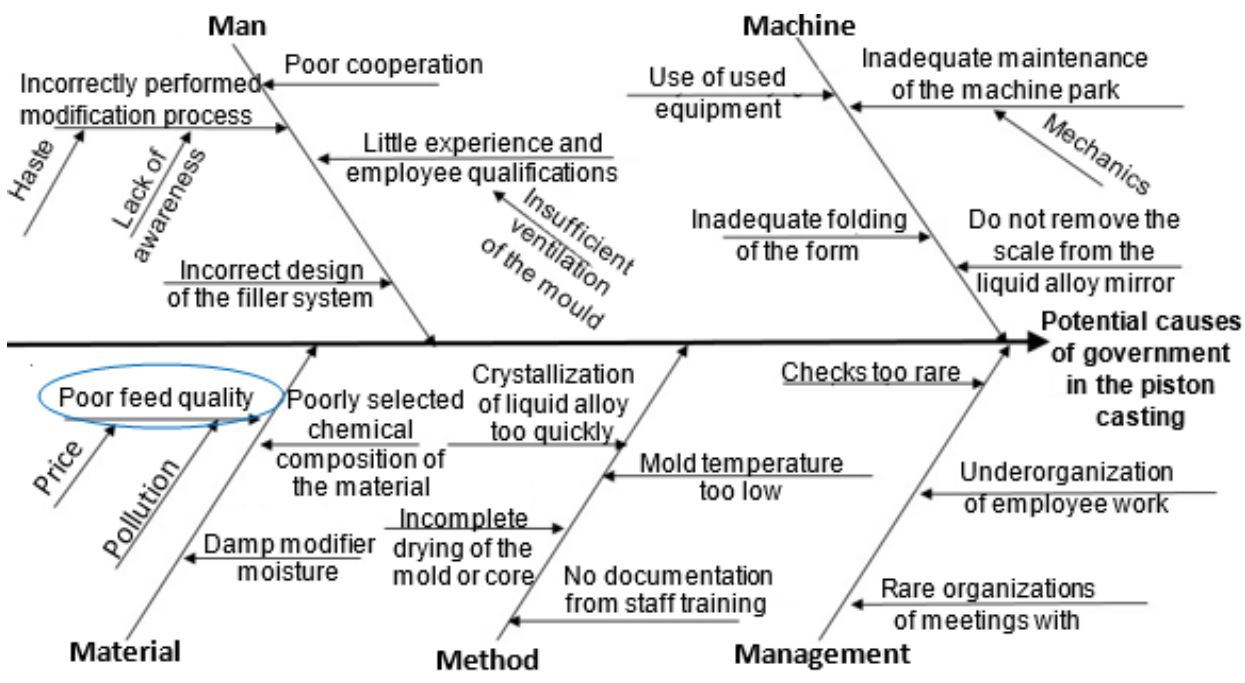

Figure 4 Ishikawa diagram for noncompliance - presence of castings in the piston casting

In order to determine the validity and rank of particular causes, the team of experts used ABCD-Suzuki method. As a result of the analyses carried out, it turned out that the three most important reasons for discontinuity of the material are, in order of importance: poor quality of the charge (contamination), incomplete drying of the mould and too fast crystallization of the liquid metal.

\section{CONCLUSION}

Diagnostic tests (visual, luminescence and microscopic examinations) used in quality control of aluminum pistons were carried out in the paper and their analysis was performed with the use of quality management 
tools. The aim of the tests was to identify non-compliant products and to check the usefulness of control and diagnostic testing in the production process.. Using visual non-destructive testing, discontinuities in the area of sealing channels were detected - casting defects. The luminescence and microscopic examination confirmed the occurrence of clusters of rhizomes in the casting. The presence of these discontinuities disqualifies the piston. In order to define the problem of discontinuity of castings, Gemba walk and 5W2H analysis were performed. In order to identify the causes of material inconsistencies, Ishikawa diagram and ABCD - Suzuki method were performed, according to which the key cause of the inconsistency was improper quality of the charge (impurities). The applied non-destructive testing method in combination with quality management methods are largely complementary. The proposed combination may be a component of methods supporting quality management processes. Traditional $5 \mathrm{~W} 2 \mathrm{H}$ can be extremely useful by incorporating it into the analysis cycle, where the output of one tool is an input to another quality management method (Ishikawa diagram). It seems to be useful for other branch of industry e.g. ribbed wire manufacturing [26], steel industry [27-29] and heavy-load biotechnological apparatus [30, 31]. Such analytical schema of inference should be taken into consideration also in similar management analyses [32-34] as well as in research analyses [35-37].

\section{REFERENCES}

[1] PACANA A., CZERWIŃSKA K. and BEDNAROWA L.. Comprehensive improvement of the surface quality of the diesel engine piston. Metalurgija. 2018. vol. 58, pp. 329-332.

[2] PACANA A., CZERWIŃSKA K. and BEDNAROWA L., Discrepancies analysis of casts of diesel engine piston, Metalurgija 57, 4, 2018, pp. 324-326.

[3] ZIMA, S.. Motorkolben: Bauarten, Betrieb, Schäden. Vieweg Verlag, 2005, p. 278.

[4] GÓRNY, Z., Szanse odlewnictwa na przykładzie wykonywania odlewów metali nieżelaznych i ich stopów. Biuletyn Metals \& Minerals, 2/2001, pp. 6-11.

[5] ESKIN G., PANOV E., BER E., STEPANOV B., BOCHVAR S. and YALFIMOV V. Effect of the casting and deformation technology on the structure and properties of quenched-and-tempered hypereutectic silumins, Metallurgist. 2008. vol. 52, pp. 388-394.

[6] CZERWIŃSKA K., DWORNICKA R. and PACANA A., Analysis of non-compliance for the cast of the industrial robot basis. In METAL 2019: $28^{\text {th }}$ Int. Conf. Metallurgy and Materials. Ostrava: TANGER, 2019, pp 644-650.

[7] SEYANIN IF., DEEV VB. and KUKHARENKO AV. Resource-saving and environment-saving production technologies of secondary aluminum alloys. Russian Journal of Non-Ferrous Metals. 2015. vol. 56, pp. 272-276.

[8] LANGABEER JR. Performance management methods and tools. In: Performance Improvement In Hospitals And Health Systems: Managing Analytics And Quality In Healthcare, $2^{\text {nd }}$ Edition. CRC Press, 2018, pp. 43-61.

[9] PAWLOWSKI K. and PAWLOWSKI E. Complementarity of modern management methods and tools, and its impact on economic and organizational performance of enterprises. In: Trzcielinski S. (eds) Advances in Ergonomics of Manufacturing: Managing the Enterprise of the Future. AHFE 2017. Advances in Intelligent Systems and Computing, vol 606. Cham: Springer, 2018, pp. 213-221.

[10] BEREZINA AL., MONASTYRSKA TO., DAVYDENKO OA., DUBODELOV VI., SPUSKANYUK VZ. and FIKSEN VN. Effect of melt treatment in magnetohydrodynamic facility and severe plastic deformation on structure and properties of silumins. Metallofizika i Noveishie Tekhnologii. 2009. vol. 31, pp. 1417-1426.

[11] NIKULIN LV. Morphology of dendritic bicrystals in hypereutectic aluminum-silicon alloys hardened in pressure casting. Metal Science and Heat Treatment. 1998. vol. 40, pp. 202-206.

[12] PIATKOWSKI J. and WIESZALA R. Influence of modifications on fatigue strength of AISi17Cu5Mg(Fe) alloy used for pistons for internal combustion engines. Arch. Metall. Mater. 2018. vol. 63, pp. 135-141.

[13] PIATKOWSKI J. AISi17Cu5Mg alloy as future material for castings of pistons for internal combustion engines. Metalurgija. 2015. vol. 54, pp. 511-514.

[14] FOREJTOVA L., ZAVADIL T., KOLARIK L., KOLARIKOVA M., SOVA J. and VAVRA P. Non-destructive inspection by infrared thermography of resistance spot welds used in automotive industry. Acta Polytechnica. 2019. vol. 59, pp. 238247. 
[15] KUTSOVA VZ., NOSKO OA. and SHERSTOBITOVA AS. Complex Modification Effect on the Structure and Properties of Industrial Piston Silumins. Metallofizika i Noveishie Tekhnologii. 2008. vol. 30, pp. 615-623.

[16] MERY D. Automated radioscopic testing of aluminum die castings. Materials Evaluation. 2006. vol. 64, pp. 135-143.

[17] OSTASZ G. et al. Quality management of aluminum pistons with the use of quality control points. Management Systems in Production Engineering. 2020. vol. 28, pp. 29-33.

[18] CZEKAJ E., SOBCZAK J. and SAJA K., Complex criterion of dimensional stability discussed on the example of piston silumins. Journal of KONES Powertrain and Transport. 2008. vol. 15, pp. 41-50.

[19] VOLOCHKO AT., KOMAROV AI., KOMAROVA VI., SENYUT VT., SHIPKO AA. and IZOBELLO AY. Tribological behavior of piston alloy reinforced by micro- and ultra-dispersed ceramic particles. Journal of Friction and Wear. 2011. vol. 32, pp. 133-139.

[20] DAVIS G., NAGARAJAH R., PALANISAMY S. and RASHID RAR. Laser ultrasonic inspection of additive manufactured components. Int. J. Adv. Manufact. Tech. 2019. vol. 102, pp. 2571-2579.

[21] BUSCHKE P. and SCHAPPACHER W., Trends in the automotive industry steer new NDT applications. Insight. 2006. vol. 48, pp. 532-536.

[22] ZHAO QH., DAN XZ., SUN FY., WANG YH., WU SJ. and YANG LX. Digital Shearography for NDT: Phase Measurement Technique and Recent Developments. Applied Sciences-Basel. 2018. vol. 8, art. 2662.

[23] ATHI N., WYLIE SR., CULLEN JD., AL-JADER M., AL-SHAMMA'A AL. and AHAW A. An online real time ultrasonic NDT system for the quality control of spot welding in the automotive industry. Sensors \& Their Applications XV. 2009. vol. 178. pp. 1-6.

[24] TITOV SA., MAEV RG. and BOGACHENKOV AN., Pulse-echo NDT of adhesively bonded joints in automotive assemblies. Ultrasonics. 2008. vol. 48, pp. 537-546.

[25] ZHANG K., HE YZ. and GONG ZR., Pulsed eddy current nondestructive testing for defect evaluation and imaging of automotive lightweight alloy materials. Journal of Sensors. 2018. vol. 2018, art. 1639387.

[26] BORKOWSKI, S., ULEWICZ, R., SELEJDAK, J., KONSTANCIAK, M. and KLIMECKA-TATAR, D. The use of 3x3 matrix to evaluation of ribbed wire manufacturing technology. In METAL 2012: 21st Int. Conf. on Metallurgy and Materials. Ostrava: TANGER, 2012, pp. 1722-1728.

[27] ULEWICZ, R., SZATANIAK, P. and NOVY, F. Fatigue properties of wear resistant martensitic steel. In METAL 2014: 23rd Int. Conf. on Metallurgy and Materials. Ostrava, TANGER, 2014, pp. 784-789.

[28] MASZKE, A., DWORNICKA, R. and ULEWICZ, R. Problems in the implementation of the lean concept at a steel works Case study. MATEC Web of Conferences. 2018. vol. 183, art. 01014.

[29] LIPINSKI, T. Double modification of AISi9Mg alloy with boron, titanium and strontium. Arch. Metall. Mater. 2015, vol. 60, pp. 2415-2419.

[30] PIETRASZEK, J. and SKRZYPCZAK-PIETRASZEK, E. The Optimization of the Technological Process with the Fuzzy Regression. Adv. Mater. Res-Switz. 2014. vol. 874, pp. 151-155.

[31] SKRZYPCZAK-PIETRASZEK, E., PISKA, K. and PIETRASZEK, J. Enhanced production of the pharmaceutically important polyphenolic compounds in Vitex agnus castus L. shoot cultures by precursor feeding strategy. Engineering in Life Sciences. 2018. vol. 18, pp.287-297.

[32] BROZOVA, S. INGALDI, M. and SPERLIN, I. Economical aspects of high-temperature heating utilization for industrial waste treatment. In METAL 2013: 22nd Int. Conf. on Metallurgy and Materials. Ostrava, TANGER, 2013, pp. 1735-1739.

[33] MALINDZAK, D., PACANA, A. and PACAIOVA, H. An effective model for the quality of logistics and improvement of environmental protection in a cement plant. Przemysl Chemiczny. 2017. vol. 96, pp. 1958-1962.

[34] ULEWICZ, R. and BLASKOVA, M. Sustainable development and knowledge management from the stakeholders' point of view. Polish Journal of Management Studies. 2018. vol. 18, pp. 363-374.

[35] STYRYLSKA, T. and PIETRASZEK, J. Numerical modeling of non-steady-state temperature-fields with supplementary data. ZAMM-Z. Angew. Math. Mech. 1992. vol. 72, pp. T537-T539.

[36] KORZEKWA, J., BARA M., PIETRASZEK, J. and PAWLUS, P. Tribological behaviour of Al2O3/inorganic fullerene-like WS2 composite layer sliding against plastic. Int. J. Surf. Sci.Eng. 2016, vol. 10, pp. 570-584.

[37] WOJNAR, L., GADEK-MOSZCZAK, A. and PIETRASZEK, J. On the role of histomorphometric (stereological) microstructure parameters in the prediction of vertebrae compression strength. Image Analysis and Stereology. 2019, vol. 38, pp.63-73. 